\title{
PENGARUH TEKANAN DAN WAKTU DEPOSISI PADA TEKNIK SPUTTERING TERHADAP TAHANAN DAN REFLEKSIVITAS LAPISAN TIPIS a-Si DAN Ag
}

\author{
Yunanto, Sudjatmoko, Trimardji Atmono, Wirjoadi \\ Puslitbang Teknologi Maju Batan Yogyakarta \\ Jl. Babarsari Kotak Pos 1008, Yogyakarta 55010
}

\begin{abstract}
ABSTRAK
PENGARUH TEKANAN DAN WAKTU DEPOSISI PADA TEKNIK SPUTTERING TERHADAP TAHANAN DAN REFLEKSIVITAS LAPISAN TIPIS a-Si DAN Ag. Telah dilakukan deposisi lopisan tipis a-Si dan Ag pada substrat kaca untuk lapisan reflektor dan lapisan untuk membuat sambungan $P-N$ untuk sel surya. Penelitian ini bertujuan mendapatkan tahanan lapisan tipis a-Si dan refleksivitas lapisan tipis Ag yang optimal, sehingga akan dipereroleh sel surya yang mempunyai efisiensi lebih tinggi. Target Si dan Ag secara terpisah ditumbuki dengan ion Ar dalam tabung sputtering, sehingga atom Si dan Ag akan terdeposisi pada substrat kaca. Untuk mengetahui struktur kristal data lapisan tipis Si diamati dengan XRD, refleksivitas lapisan tipis Ag menggunakan UV-Vis dan tahanan lapisan tipis Si dengan multimeter digital. Dari hasil pengamatan diperoleh hasil bahwa lapisan tipis Si menunjukkan amorf, refleksivitas tertinggi lapisan tipis Ag 78 \% dan tahanan terkecil lapisan tipis a-Si: 77 mega $\mathrm{Ohm}$.
\end{abstract}

\begin{abstract}
THE INFLUENCE OF THE PRESSURE AND THE DEPOSITION TIME ON THE SPUTTERING TECHNIQUE AGAINST THE RESISTANCE AND REFLECTIVITY OF a-Si AND Ag THIN FILM. The deposition of thin films a-Si and Ag onto the glass substrate to make the reflector and the PN-junction for the solar cell has been done. The aim of the research was to get the optimal value of the resistance of thin film a-Si and the reflectivity of thin film Ag, so that the efficiency of the solar cell turn higher. The bombardement of Si- and Ag-target was occurred separately by the Argon-ion in the sputtering-chamber, so that the Si- and Ag-atom were deposited onto glass substrate. The crystal structure of thin film a-Si was investigated with the XRD, the UV-Vis and the digital multimeter used to measure the reflectivity of thin film Ag and the resistance a-Si, respectively. The research shows the following results: the thin film a-Si was amorf the best reflectivity of thin film $\mathrm{Ag}$ was $78 \%$ and the smallest resistance of a-Si- thin film was 77 mega Ohm.
\end{abstract}

\section{PENDAHULUAN}

$P^{3}$ ada tahun terakhir ini banyak dilakukan penelitian penggunan bahan silikon amorf a-Si untuk pembuatan sel surya. Penggunaan bahan a-Si disebabkan karena dalam pembuatan bahan semikonduktor tersebut lebih mudah dari pada menggunakan silikon kristal, sehingga harganya dapat ditekan lebih murah, mempunyai lebar pita yang lebih lebar yaitu $1,7 \mathrm{eV}$ yang akan menimbulkan rekombinasi yang lebih besar, sehingga akan menaikkan efisiensi. Sel surya dengan bahan a-Si dibuat lapisan tipis, sehingga hanya dibutuhkan bahan a-Si dengan jumlah yang jauh lebih sedikit. Selain kelebihan tersebut bahan a-Si juga mempunyai kekurangan yaitu konduktivitasnya lebih rendah, dengan demikian bila digunakan untuk sel surya mempunyai efisiensi yang lebih rendah. Tetapi hal ini dapat diatasi dengan menambahkan unsur $\mathrm{H}$ pada bahan a-Si yang dapat menghubungkan lengan kosong.

Susunan lapisan tipis untuk sel surya yang menggunakan bahan a-Si yaitu elektroda depan yang dibuat dari bahan TCO (Transparent Conducting Oxide) berfungsi untuk mengambil arus, lapisan sambungan P-N untuk membangkitkan tegangan sel surya (bila sambungan P-N dikenai cahaya) 
dan elektroda belakang untuk mengambil arus juga sebagai lapisan reflektor. Reflektor ini berfungsi untuk meningkatkan pantulan cahaya pada daerah panjang gelombang $600 \mathrm{~nm}$ sampai dengan $800 \mathrm{~nm}$ yang masuk melewati sambungan P-N dan untuk meningkatkan arus hubung singkat (akan meningkatkan efisiensi sel surya). Homogenitas lapisan tipis Ag dan a-Si juga mempunyai peranan untuk meningkatkan efisiensi. Reflektor dari lapisan tipis Ag ini selain harus dapat merefleksikan cahaya secara optimum, juga harus dapat mengambil arus juga secara optimum. Reflektor biasanya dibuat dari $\mathrm{Al}, \mathrm{Au}, \mathrm{Ag}$ yang masing-masing mempunyai refleksivitas pada panjang gelombang $600 \mathrm{~nm}$ sampai 800 nm $86 \%$ - $91 \%$, 91\% - 98 \%, 98 \% - $99 \%$. Pada penelitian ini dipilih Ag yang mempunyai refleksivitas dan konduktivitas yang paling besar.

Suatu logam mempunyai sifat memantulkan (refleksivitas) terhadap cahaya yang mengenai permukaan logam tersebut dan tergantung pada logamnya. Refleksivitas suatu logam selain tergantung dari jenis logamnya, juga tergantung pada kekasaran permukaan suatu logam itu sendiri. Cahaya yang mengenai permukaan suatu logam akan direfleksikan jika kedalaman rata-rata dan ketidak teraturan permukaan reflektor jauh lebih kecil dari pada panjang gelombang cahaya yang datang. Selain itu ukuran rentang dari reflektor harus jauh lebih besar dari pada panjang gelombang cahaya yang datang.

Pembuatan lapisan tipis Ag dan lapisan tipis a-Si dilakukan dengan teknik sputtering. Parameter sputtering adalah : tekanan gas Ar, suhu substrat, jarak elektroda, waktu deposisi dan daya elektroda. Dengan melakukan variasi tekanan gas Ar dan waktu deposisi diharapkan akan diperoleh lapisan tipis a-Si yang mempunyai tahanan yang cukup rendah dan lapisan tipis Ag yang mempunyai refleksivitas yang cukup tinggi.

\section{TATA KERJA}

Dalam penelitian ini dilakukan beberapa tahapan yang meliputi : penyiapan cuplikan, pendeposisian lapisan tipis, pengukuran tahanan lapisan tipis a-Si, pengamatan struktur kristal dan pengukuran prosentase refleksivitas.

\section{Penyiapan Cuplikan}

Bahan yang digunakan dalam penelitian ini adalah target Si dan Ag dengan diameter $75 \mathrm{~mm}$ tebal $2 \mathrm{~mm}$. Sedangkan bahan untuk substrat digunakan kaca dipotong dengan ukuran $10 \mathrm{~mm}$ x $10 \mathrm{~mm}$.

\section{Pendeposisian Lapisan Tipis}

Peralatan RF sputtering yang digunakan terdiri diri : tabung sputtering dengan dua target Si dan Ag, pompa vakum rotari, pompa vakum turbo, vakum meter, sumber tegangan tinggi RF, matching box, pendingin target. dan sumber gas argon.

Target Si dan Ag diletakkan pada tempat target secara terpisah yang berfungsi juga sebagai katoda di dalam tabung sputtering. Substrat kaca diletakkan pada anoda yang berada di atas katoda. Tabung sputtering divakumkan dengan pompa rotari dan turbo sampai $5 \times 10^{-6}$ Torr (untuk membersihkan partikel yang tidak dikehendaki), kemudian gas argon dialirkan ke dalam tabung sputtering melalui kran yang digunakan untuk mengatur tekanan gas. Tekanan gas akan naik dan ditentukan menjadi $7 \times 10^{-1}$ Torr.

Sumber tegangan tinggi RF dihidupkan dengan mengatur daya RF pada daya tertentu dengan mengatur matching box. Gas argon di dalam tabung sputtering terionisasi, ion argon akan menumbuki target Si atau Ag. Substrat kaca mendapat percikan ion $\mathrm{Si}$ maupun Ag dengan tenaga yang cukup besar, sehingga atom Si maupun Ag akan merekat dengan kuat pada substrat kaca. Untuk mendapatkan lapisan tipis a-Si yang mempunyai tahanan yang cukup rendah dan lapisan tipis yang mempunyai refleksivitas yang cukup tinggi, maka dilakukan variasi waktu deposisi dari 10 menit sampai 30 
menit dan variasi tekanan gas dari $7 \times 10^{-1}$ Torr sampai dencran $1,5 \times 10^{-1}$ Torr.

\section{Pengukuran Tahanan Lapisan Tipis Si pada Substrat Kaca}

Untuk mengetahui tahanan lapisan tipis

Si dideposisikan pada substrat kaca, maka lapisan tipis tersebut diukur tahanannya dengan digital multimeter. Tahanan dari lapisan tipis a-Si tergantung dari ketebalan lapisan tipis. Semakin tebal lapisan tipis a-Si tahanannya akan semakin mengecil. Ketebalan dari lapisan tipis tergantung dari waktu deposisi dan tekanan gas Ar.

\section{Pengukuran Struktur Kristal Dengan XRD.}

Untuk membuat sel surya dengan efisiensi yang lebih tinggi maka bahan Si harus amorf. Untuk mengetahui apakah bahan Si yang terdeposisi pada substrat kaca adalah amorf maka struktur kristalnya harus diamati dengan XRD.

\section{Pengukuran Prosentase Reflektansi Lapisan Tipis Ag}

Pengukuran prosentase reflektansi lapisan tipis Ag dilakukan dengan menggunakan alat UV-Vis. Alat ini pada dasarnya terdiri dari sumber cahaya, monokromator, tempat cuplikan, detektor cahaya penguat tegangan dan penampil. Sumber cahaya terdiri dari lampu lucutan hidrogen (untuk panjang, gelombang $150 \mathrm{~nm}$ sampai dengan $350 \mathrm{~nm}$ ) dan lampu wolfram (untuk panjang gelombang $350 \mathrm{~nm}$ sampai $1.000 \mathrm{~nm}$ ). Alat yang digunakan dapat divariasi panjang gelombangnya dari $190 \mathrm{~nm}$ sampai dengan $950 \mathrm{~nm}$. Cahaya dari sumber cahaya dilewatkan pada lensa monokromator, sehingga akan terjadi cahaya dengan berbagai panjang gelombang. Lensa monokromator ini diputar secara perlahan sehingga akan menghasilkan cahaya yang berubah panjang gelombangnya secara perlahan-lahan dan ditangkap oleh detektor cahaya yang dibuat dari photo elektrik. Keluaran dari detektor ini diperkuat dengan penguat tegangan dan ditampilkan pada layar komputer hubungan antara panjang gelombang dan transmitansi dari cuplikan.

\section{HASIL DAN PEMBAHASAN}

Pada penelitian ini untuk membuat lapisan tipis a-Si dan Ag pada substrat kaca menggunakan RF sputtering yang mempunyai keunggulan dibandingkan dengan DC sputtering. Salah satunya adalah rapat plasmanya yang tinggi sehingga akan diperoleh lapisan tipis dengan waktu lebih singkat. Pengamatan hasil lapisan tipis a-Si dan Ag antara lain : pengamatan hubungan antara tekanan gas dan waktu deposisi dengan tahanan lapisan tipis a-Si, struktur kristal lapisan tipis a-Si, hubungan antara tekanan gas Ar dan waktu deposisi dengan prosentase refleksivitas lapisan tipis Ag disajikan pada Gambar 1 sampai dengan Gambar 8.

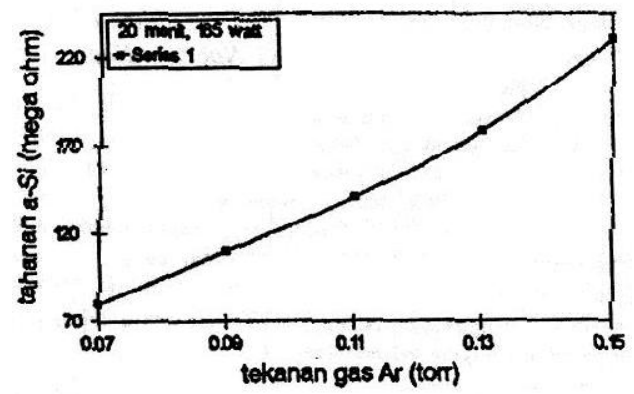

Gambar 1. Grafik hubungan antara tekanan gas Ar dengan tahanan lapisan tipis a-Si.

Pada Gambar 1 disajikan grafik hubungan antara tekanan gas Ar dengan tahanan lapisan tipis a-Si. Tahanan lapisan tipis a-Si cenderung naik dengan naiknya tekanan gas Ar. Hal ini disebabkan karena dengan naiknya tekanan gas Ar maka jalan bebas rata-rata ion $\mathrm{Ar}$ menjadi panjang, sehingga tenaga ion Ar untuk menumbuk target Si berkurang. Percikan atom Si yang merekat pada substrat kaca juga semakin menurun. Penurunan percikan atom Si ini akan mengurangi ketebalan lapisan tipis Si pada substrat kaca. Substrat kaca mempunyai tahanan yang sangat besar, sehingga dengan 
berkurangnya ketebalan lapisan tipis, maka tahanan lapisan tipis a-Si akan berkurang.

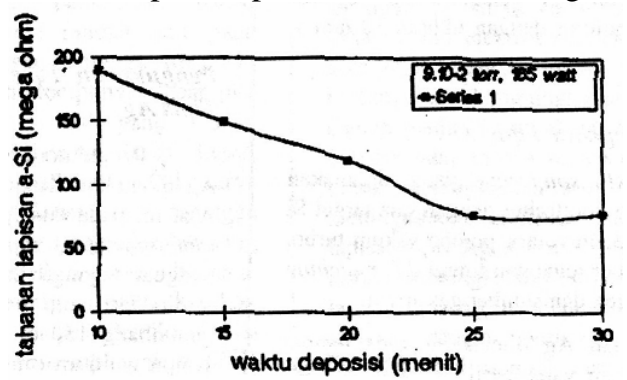

Gambar 2. Grafik hubungan antara waktu deposisi dengantahanan lapisan tipis a-Si.

Pada Gambar 2 disajikan grafik hubungan antara waktu deposisi dengan tahanan lapisan tipis a-Si. Tahanan lapisan tipis cenderung berkurang dengan meningkatnya waktu deposisi, hal ini disebabkan karena dengan parameter selain waktu deposisi yaitu daya RF, jarak elektroda, tekanan gas Ar tetap. Maka jumlah percikan atom Si pada substrat kaca adalah konstan, sehingga dengan meningkatnya waktu deposisi, lapisan tipis a-Si yang terbentuk pada substrat kaca akan semakin tebal. Dengan meningkatnya ketebalan lapisan tipis a-Si maka tahanan lapisan tipis akan menurun.

Pada Gambar 3 disajikan grafik hubungan antara tekanan gas Ar dengan refleksivitas lapisan tipis Ag. Refleksivitas lapisan tipis Ag cenderung menurun dengan naiknya tekanan gas Ar. Hal ini disebabkan tekanan gas yang semakin tinggi maka jalan bebas rata-rata ion Ar akan semakin panjang atau semakin tinggi tekanan gas Ar, di dalam tabung sputtering semakin banyak partikel lain yang masuk. Dengan demikian semakin banyak tumbukan antara ion Ar sendiri dan partikel lain yang tidak diinginkan.

Tumbukan ini akan menyebabkan ion Ar akan kehilangan sebagian tenaga untuk menumbuki target Ag, sehingga percikan atom Ag semakin berkurang. Berkurangnya ketebalan lapisan tipis Ag akan menyebabkan kekasaran pada permukaan lapisan tipis meningkat. Kekasaran permukaan suatu logam selain tergantung dari jenis logam juga dari terbentuknya logam tersebut.. Cahaya yang mengenai permukaan suatu logam akan direfleksikan jika kedalaman rata-rata dan ketidak teraturan permukaan relektor jauh lebih kecil dari pada panjang gelombang cahaya yang datang. Selain itu ukuran rentang dari reflektor harus jauh lebih besar dari pada panjang gelombang cahaya yang datang.

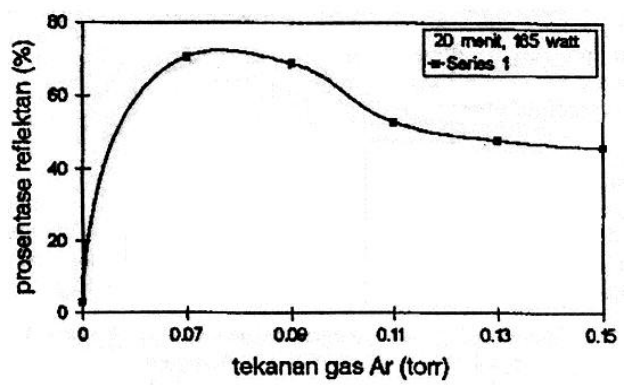

Gambar 3. Grafik bubungan antara tekanan gas Ar dengan prosentase refleksivitas.

Pada Gambar 4 disajikan grafik hubungan antara waktu deposisi dengan prosentase refleksivitas lapisan tipis Ag. Untuk parameter sputtering yaitu tekanan gas $\mathrm{Ar}$, daya RF dan jarak elektroda tetap maka dengan bertambahnya waktu deposisi maka ketebalan tapisan tipis akan meningkat. Peningkatan ketebalan lapisan tipis ini akan meningkadm kerapatan susunan atom Ag, sehingga memperbaiki permukaan lapisan tipis. Dengan demikian cahaya yang datang banyak yang dipantulkan kembali.

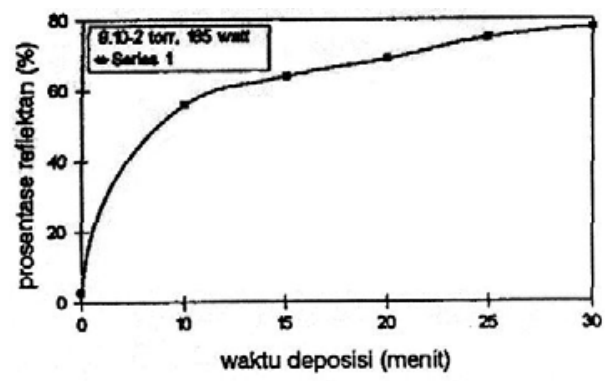

Gambar 4. Grafik hubungan antara waktu deposisi dengan prosentase refleksivitas lapisan tipis Ag. 
Proses pertumbuhan lapisan tipis pada suatu substrat melalui beberpa proses yaitu proses statistik dari nukleasi, difusi atom asing pada permukaan substrat dan pembentukan struktur jaringan yang mengisi seluruh permukaan substrat membentuk lapisan tipis. Proses pertumbuhan lapisan tipis ditentukan oleh parameter termodinamika dari deposisi pada substrate. Hasil dari deposisi dapat menghasilkan berupa pulau-pulau, lapisan tipis dan campuran lapisan tipis dan pulau. Jadi lapisan tipis yang menghasilkan prosentase refleksivitas yang cukup tinggi lapisan tipisnya berupa lapisan tipis lapisan tipis yang mempunyai permukaan lebih rata.

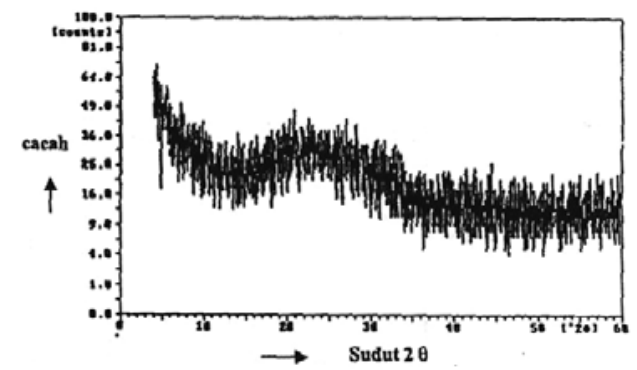

Gambar 5. Spektrum dari lapisan tipis a-Si menggunakan XRD.

Lapisan tipis a-Si yang terdeposisi pada substrat kaca diamati struktur kristalnya dengan XRD. Dari hasil pengamatan yang disajikan pada Gambar 5 tidak diperoleh satupun puncak yang muncul, sehingga struktur dari lapisan tipis Si adalah amorf. Salah satu prinsip pada XRD yang biasa digunakan adalah metode pemutaran kristal tunggal dalam suatu berkas sinar $\mathrm{X}$ monokromator. Berkas sinar $\mathrm{X}$ ini berasal dari elektroda yang ditembaki dengan elektron kecepatan tinggi.

Panjang gelombang sinar $\mathrm{X}$ dibuat tetap, sedangkan yang dirubah sudut kristal tunggal yang diputar. Dengan demikian akan terpenuhi hukum Bragg (apabila cuplikan yang diamati mempunyai susunan atom kristal) yaitu masing-masing bidang yang berbeda pada kristal akan mempunyai posisi pantulan tertentu untuk masing-masing bidang yang berputar pada cuplikan. Kristal biasanya berorientasi sedemikian rupa sehingga rotasi terjadi pada salah satu sumbu atom. Tetapi apabila cuplikan yang diamati tidak mempunyai susunan atom yang berbentuk kristal, maka tidak terjadi pantulan, sehingga tidak menghasilkan sinyal pada spektrum XRD.

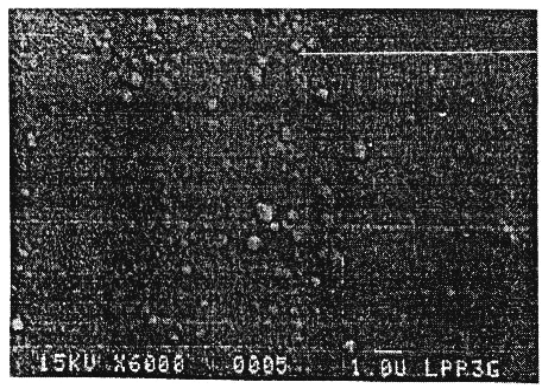

Gambar 6. Struktur mikro permukaan lapisan tipis Ag menggunakan SEM perbesaran $6000 \times$

Gambar 6. menyajikan gambar permukaan lapisan tipis Ag diamati struktur mikronya menggunakan SEM. Pada Gambar tersebut terlihat permukaan lapisan tipis Ag tidak rata banyak terdapat lubang. Lubang-lubang inilah yang tidak memantulkan keseluruhan cahaya datang kembali ke sumber cahaya, sehingga prosentase refleksivitasnya tidak terlalu tinggi. Demikian juga pada pengamatan struktur mikro dengan arah melintang, terlihat juga permukaan lapisan tipis tidak rata (pada Gambar 7).

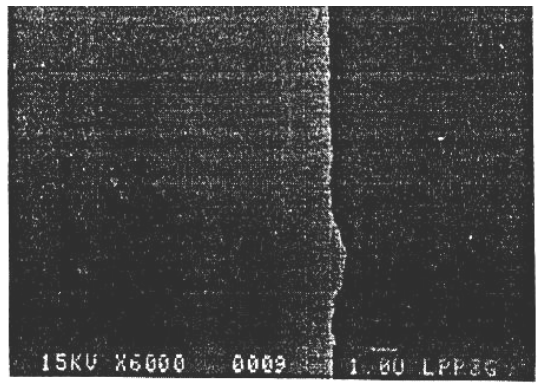

Gambar 7. Struktur mikro tampang lintang lapisan tipis Ag menggunakan SEM perbesaran $6000 \times$. 


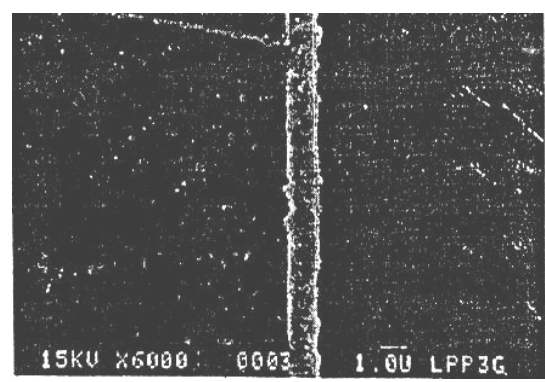

Gambar 8. Stuktur mikro tampang lintang (ketebalan) dua lapis lapisan tipis Ag dan a-Si perbesaran $6000 \times$

Dengan mengamati penampang melintang substrat yang sudah dideposisi seperti Gambar 8, maka terlihat adanya lapisan tipis Ag setebal $1 \mu \mathrm{m}$ yang berwarna agak kehitaman dan lapisan tipis a-Si setebal $0,5 \mu \mathrm{m}$ berwarna putih pada permukaan. Pengamatan ini menunjukkan telah terbentuk lapisan tipis Ag pada substrat kaca dan lapisan tipis a-Si pada permukaan lapisan tipis Ag. Sedangkan diantara lapisan tipis Ag dan lapisan tipis Si tidak terlihat lapisan tipis pengotor yang lain. Hal ini disebabkan karena dalam pembuatan kedua lapisan tipis tersebut menggunakan tempat target dua buah yaitu tempat target Ag dan $\mathrm{Si}$, sehingga dalam pembuatan lapisan tipis tanpa membuka tabung sputtering.

\section{KESIMIPULAN}

Dari hasil percobaan dan pengamatan yang telah dilakukan dapat diambil beberapa kesimpulan,bahwa dengan menggunakan teknik sputtering dapat dibuat lapisan tipis a-Si dan lapisan tipis Ag pada substrat kaca. Semakin tinggi tekanan maka tahanan lapisan tipis a-Si semakin besar dari 80 mega Ohm menjadi 231 mega Ohm sedangkan refleksivitasnya menurun dari $71 \%$ menjadi $46 \%$. Semakin lama waktu deposisi tahanan a-Si akan semakin mengecil dari 100 mega Ohm menjadi 77 mega Ohm, sedangkan refleksivitasnya semakin naik dari $56 \%$ menjadi 78 \%. Lapian tipis a-Si mempunyai struktur kristal amorf yang mempunyai daerah rekombinasi lebih lebar, sehingga cocok untuk sel surya. Lapisan tipis Ag masih terdapat lubang dan permukaannya tidak begitu rata, sehingga mengurangi prosentase refreksivitas.

\section{UCAPAN TERIMA KASIH}

Penulis mengucapkan terima kasih kepada Sdr. Giri Slamet yang telah membantu membuat lapisan tipis Ag dan a-Si dan Sdri. Endang Nawangsih, Amd yang telah mengamati prosentase refleksivitas menggunakan UV-Vis.

\section{DAFTAR PUSTAKA}

1. K. TAKAHASHI, M. KONAGAI, Amorphose Silicon Solar Cells, North Oxford Academic, (1986).

2. TADATSUGU MINAMI, HIDEO SONOHARA, SHINZO TAKATA, ICHIRO FUKUDA, Low Temperature Formation of Textured $\mathrm{ZnO}$ Transparent Electrodes by Magnetron Sputtering, J. Vac. Sci. Technol, A 13(3), May/June (1995).

3. GEORGE HASS, MAURICE H, JOHN L VOSSEN, Physics of Thin Film, Academic Press, New York, (1992).

4. SHINICHROU, MASAHIRO, YASHINO, KATAHARA, KAZUHISA, Improvement orPerformance of a-Si/a-Si Double Junction Solar Cell by Utilizing the ZnO/Ag Rear Contact, 14 th European Photo Voltaic Conference and Exhibition, (1997).

5. HALLIDAY, RESNICK, PANTUN SILABAN, ERWIN SUCIPTO, Fisika, Erlangga, Jakarta, (1984).

6. KIYOTAKA WASA, SHIGERU HAYAKAWA, Handbook of Sputtering Deposition Technology, Noyes Publications, Park Rudge, (1991). 